\title{
An efficient 2.5D inversion of loop-loop electromagnetic data
}

\author{
Yoonho Song ${ }^{1,3}$ Jung-Ho Kim² \\ ${ }^{1}$ Groundwater and Geothermal Resources Division, Korea Institute of Geoscience and Mineral \\ Resources (KIGAM), 30 Gajeong-Dong, Yuseong-Gu, Daejon 305-350, Korea. \\ ${ }^{2}$ Geoelectric Imaging Laboratory, Korea Institute of Geoscience and Mineral Resources (KIGAM), \\ 30 Gajeong-Dong, Yuseong-Gu, Daejon 305-350, Korea. \\ ${ }^{3}$ Corresponding author. Email: song@kigam.re.kr
}

\begin{abstract}
We have developed an inversion algorithm for loop-loop electromagnetic (EM) data, based on the localised nonlinear or extended Born approximation to the solution of the 2.5D integral equation describing an EM scattering problem. Source and receiver configuration may be horizontal co-planar (HCP) or vertical co-planar (VCP). Both multi-frequency and multi-separation data can be incorporated. Our inversion code runs on a PC platform without heavy computational load.

For the sake of stable and high-resolution performance of the inversion, we implemented an algorithm determining an optimum spatially varying Lagrangian multiplier as a function of sensitivity distribution, through parameter resolution matrix and Backus-Gilbert spread function analysis. Considering that the different source-receiver orientation characteristics cause inconsistent sensitivities to the resistivity structure in simultaneous inversion of HCP and VCP data, which affects the stability and resolution of the inversion result, we adapted a weighting scheme based on the variances of misfits between the measured and calculated datasets.

The accuracy of the modelling code that we have developed has been proven over the frequency, conductivity, and geometric ranges typically used in a loop-loop EM system through comparison with 2.5D finite-element modelling results. We first applied the inversion to synthetic data, from a model with resistive as well as conductive inhomogeneities embedded in a homogeneous half-space, to validate its performance. Applying the inversion to field data and comparing the result with that of $\mathrm{dc}$ resistivity data, we conclude that the newly developed algorithm provides a reasonable image of the subsurface.
\end{abstract}

Key words: electromagnetic (EM), 2.5D, inversion, localised non-linear approximation.

\section{Introduction}

The loop-loop EM method is one of the oldest geophysical techniques, and has been used for over 70 years, mainly in mineral exploration (Spies and Frischknecht, 1991). Recently, the method has been applied in wider fields, including environmental site characterisation surveys to detect landfills and buried metallic drums containing hazardous waste (Won et al., 1996). The method offers rapid delineation of subsurface structure, and is quite useful where the contact with the ground is not appropriate to deploy resistivity surveys, or where the surface is covered with contaminated materials.

In spite of its diverse applications, the interpretation of loop-loop EM data has generally been based on simple onedimensional (1D) inversion, or some restricted quantitative analysis (Frischknecht et al., 1991; Spies and Frischknecht, 1991). This relative absence of automated and quantitative interpretation tools may be partially because fully digital equipment, accommodating multi-frequency as well as multiseparation operations, has only recently been released to the market. Another reason may be that a fast 2.5D EM inversion scheme is not readily available, as the use of a rigorous modelling algorithm is still expensive for field applications.

In this study, we have developed an efficient 2.5D inversion scheme for frequency domain loop-loop EM data, which runs on a PC platform without heavy computational load. We used the localised non-linear (LN) approximation (Habashy et al., 1993) to the 2.5D EM integral equation solution for forward computation, as used by Torres-Verdin and Habashy (1994), but with different derivations in detail. In the inversion procedure, we implemented the spatially variable Lagrangian multiplier scheme (Yi et al., 2003) in order to enhance the resolution. Because the variances of the misfits are different from horizontal coplanar (HCP) to vertical coplanar (VCP) configuration, due to different sensitivities, we also implemented a weighting scheme for the Jacobian, based on the misfit variances.

We first test the performance of the algorithm that we have developed with a set of synthetic models. We then apply it to field data gathered at an agricultural site in Korea, and compare the resultant 2D images with dipole-dipole resistivity survey results along the same profile line.

\section{LN approximation to the 2.5D EM integral equation}

The electric field at $\mathbf{r}$ anywhere in volume $V$ can be expressed by Fredholm's integral equation of the second kind,

$$
\mathbf{E}(\mathbf{r})=\mathbf{E}^{p}(\mathbf{r})-\hat{z} \int_{V} \underline{\mathbf{G}}^{E}\left(\mathbf{r}, \mathbf{r}^{\prime}\right) \cdot \Delta \sigma\left(\mathbf{r}^{\prime}\right) \mathbf{E}\left(\mathbf{r}^{\prime}\right) d \mathbf{r}^{\prime},
$$

where $\mathbf{E}^{p}(\mathbf{r})$ is the background electric field in the absence of the conductivity inhomogeneity, $\hat{z}=i \omega \mu$ the impedivity, $\omega$ the angular frequency, $\mu$ the magnetic permeability assumed to be that of free space, $\underline{G}^{E}\left(\mathbf{r}, \mathbf{r}^{\prime}\right)$ the electric Green's tensor which relates the electric field at $\mathbf{r}$ due to the current source at $\mathbf{r}^{\prime}$ with 
the moment of $-1 / \hat{z}$, and $\Delta \sigma\left(\mathbf{r}^{\prime}\right)=\sigma\left(\mathbf{r}^{\prime}\right)-\sigma_{b}$ is the anomalous conductivity with $\sigma_{b}$ being the background value (Hohmann, 1975).

Taking the curl of equation (1), the magnetic field can be expressed as the sum of the background or primary field and the secondary field in terms of the integral of the anomalous or scattering currents:

$$
\begin{aligned}
\mathbf{H}(\mathbf{r}) & =\mathbf{H}^{p}(\mathbf{r})+\mathbf{H}^{s}(\mathbf{r}) \\
& =\mathbf{H}^{p}(\mathbf{r})-\hat{z} \int_{V} \underline{\underline{G}}^{H}\left(\mathbf{r}, \mathbf{r}^{\prime}\right) \cdot \Delta \sigma\left(\mathbf{r}^{\prime}\right) \mathbf{E}\left(\mathbf{r}^{\prime}\right) d \mathbf{r}^{\prime},
\end{aligned}
$$

where

$$
\underline{\underline{\mathbf{G}}}^{H}\left(\mathbf{r}, \mathbf{r}^{\prime}\right)=-\frac{1}{\hat{z}} \nabla \times \underline{\underline{G}}^{E}\left(\mathbf{r}, \mathbf{r}^{\prime}\right)
$$

is the magnetic Green's tensor.

In a $2 \mathrm{D}$ earth with the $y$-axis as the strike direction, the conductivity becomes a function of $x$ and $z$ only:

$$
\Delta \sigma\left(\mathbf{r}^{\prime}\right)=\Delta \sigma\left(x^{\prime}, z^{\prime}\right),
$$

and equation (2) can be written as

$$
\begin{aligned}
\mathbf{H}(x, y, z)= & \mathbf{H}^{p}(x, y, z)-\hat{z} \int_{V} \underline{\underline{\mathbf{G}}}^{H}\left(x-x^{\prime}, y-y^{\prime}, z ; z^{\prime}\right) \\
& \cdot \Delta \sigma\left(x^{\prime}, z^{\prime}\right) \mathbf{E}\left(x^{\prime}, y^{\prime}, z^{\prime}\right) d x^{\prime} d y^{\prime} d z^{\prime} .
\end{aligned}
$$

Rewriting the above convolution integral in wavenumber domain with respect to the $y$-axis,

$$
\begin{aligned}
\mathbf{H}(x, y, z)= & \mathbf{H}^{p}(x, y, z)-\frac{\hat{z}}{2 \pi} \int_{-\infty}^{\infty}\left[\int_{S} \underline{\underline{\mathbf{G}}}^{H}\left(x-x^{\prime}, k_{y}, z ; z^{\prime}\right)\right. \\
& \left.\cdot \Delta \sigma\left(x^{\prime}, z^{\prime}\right) \tilde{\mathbf{E}}\left(x^{\prime}, k_{y}, z^{\prime}\right) d x^{\prime} d z^{\prime}\right] e^{i k_{y} y} d k_{y}
\end{aligned}
$$

and in turn

$$
\begin{gathered}
\tilde{\mathbf{H}}\left(x, k_{y}, z\right)=\tilde{\mathbf{H}}^{p}\left(x, k_{y}, z\right)-\hat{z} \int_{S} \underline{\underline{\mathbf{G}}}^{H}\left(x-x^{\prime}, k_{y}, z ; z^{\prime}\right) \\
\cdot \Delta \sigma\left(x^{\prime}, z^{\prime}\right) \tilde{\mathbf{E}}\left(x^{\prime}, k_{y}, z^{\prime}\right) d x^{\prime} d z^{\prime} .
\end{gathered}
$$

Here the tilde (' $\sim$ ' sign) denotes the Fourier-transformed quantity with respect to $y$. The equations (6) and (7) constitute the basic formulation of the 2.5D integral equation approach to the solution of the EM scattering problem, with a harmonic electric field satisfying

$$
\begin{gathered}
\tilde{\mathbf{E}}\left(x, k_{y}, z\right)=\tilde{\mathbf{E}}^{p}\left(x, k_{y}, z\right)-\hat{z} \int_{S} \underline{\underline{\mathbf{G}}}^{E}\left(x-x^{\prime}, k_{y}, z ; z^{\prime}\right) \\
\cdot \Delta \sigma\left(x^{\prime}, z^{\prime}\right) \tilde{\mathbf{E}}\left(x^{\prime}, k_{y}, z^{\prime}\right) d x^{\prime} d z^{\prime},
\end{gathered}
$$

and we are able to evaluate the response of the $2 \mathrm{D}$ earth while maintaining the 3D nature of the EM source.

Now, applying the LN or extended Born approximation (Habashy et al., 1993) to the above 2.5D integral equation,

$$
\begin{aligned}
\tilde{\mathbf{E}}\left(x, k_{y}, z\right)= & \tilde{\mathbf{E}}^{p}\left(x, k_{y}, z\right)-\hat{z} \int_{S} \underline{\underline{\mathbf{G}}}^{E}\left(x-x^{\prime}, k_{y}, z ; z^{\prime}\right) \\
& \cdot \Delta \sigma\left(x^{\prime}, z^{\prime}\right)\left[\tilde{\mathbf{E}}\left(x^{\prime}, k_{y}, z^{\prime}\right)-\tilde{\mathbf{E}}\left(x, k_{y}, z\right)\right] d x^{\prime} d z^{\prime} \\
& -\hat{z} \int_{S} \underline{\tilde{\mathbf{G}}}^{E}\left(x-x^{\prime}, k_{y}, z ; z^{\prime}\right) \Delta \sigma\left(x^{\prime}, z^{\prime}\right) d x^{\prime} d z^{\prime} \\
& \cdot \tilde{\mathbf{E}}\left(x, k_{y}, z\right)
\end{aligned}
$$

we arrive at

$$
\tilde{\mathbf{E}}\left(x, k_{y}, z\right) \approx \underline{\underline{\boldsymbol{\Gamma}}}\left(x, k_{y}, z\right) \cdot \tilde{\mathbf{E}}^{p}\left(x, k_{y}, z\right),
$$

where the depolarisation or scattering tensor in the wavenumber domain is expressed as

$\underline{\underline{\mathbf{\Gamma}}}\left(x, k_{y}, z\right)=\left[\underline{\underline{\mathbf{I}}}+\hat{z} \int_{S} \underline{\underline{\mathbf{G}}}^{E}\left(x-x^{\prime}, k_{y}, z ; z^{\prime}\right) \Delta \sigma\left(x^{\prime}, z^{\prime}\right) d x^{\prime} d z^{\prime}\right]^{-1}$.

The LN approximate formulas, equations (10) and (11), differ from those by Torres-Verdin and Habashy (1994) in that we apply the $\mathrm{LN}$ approximation to the $2.5 \mathrm{D}$ integral equation itself, while they used a 3D approximate formula and a 2D formulation of the scattering tensor through an infinite integral over $y$-axis.

\section{Numerical modelling}

To get a numerical solution with the 2.5D LN approximation, we divide the inhomogeneity, or the region including anomalies, into a finite number of cells, $N$, having constant conductivity and constant electric field over each cell, to arrive at the following equation for the secondary field:

$$
\begin{aligned}
\tilde{\mathbf{H}}^{s}\left(x, k_{y}, z\right)= & -\hat{z} \sum_{k=1}^{N} \Delta \sigma_{k}\left[\int_{S_{k}} \underline{\tilde{\mathbf{G}}}^{H}\left(x-x^{\prime}, k_{y}, z ; z^{\prime}\right) d S^{\prime}\right. \\
& \left.\cdot \tilde{\underline{\boldsymbol{\Gamma}}}_{k} \cdot \tilde{\mathbf{E}}^{p}\left(x_{k}, k_{y}, z_{k}\right)\right],
\end{aligned}
$$

where

$$
\begin{aligned}
\underline{\underline{\tilde{\boldsymbol{\Gamma}}}}_{k} & =\underline{\underline{\tilde{\boldsymbol{\Gamma}}}}\left(x_{k}, k_{y}, z_{k}\right) \\
& =\left[\underline{\underline{\mathbf{I}}}+\hat{z} \sum_{l=1}^{N} \Delta \sigma_{l} \int_{S_{l}} \underline{\tilde{\mathbf{G}}}^{E}\left(x_{k}-x^{\prime}, k_{y}, z_{k} ; z^{\prime}\right) d S^{\prime}\right]^{-1} .
\end{aligned}
$$

We selected a total of 15 spatial wavenumbers, equally spaced on a logarithmic scale, covering the range from $0.1 \mathrm{~m}$ to 4 skin depths in the space domain. Once the spatial harmonic secondary magnetic fields are computed over these 15 spatial wavenumbers, the inverse Fourier transform is to be done through numerical integration, with cubic spline interpolation to get the responses along the profile. The primary magnetic fields over the homogeneous half-space are calculated in the space domain with a numerical Hankel transform technique using Gaussian quadrature (Chave, 1983).

Figure 1 shows a conductive block model used in testing the validity of the $2.5 \mathrm{D}$ modelling and inversion. A conductive block of $10 \Omega . m$ is located at $15 \mathrm{~m}$ depth in a homogeneous half-

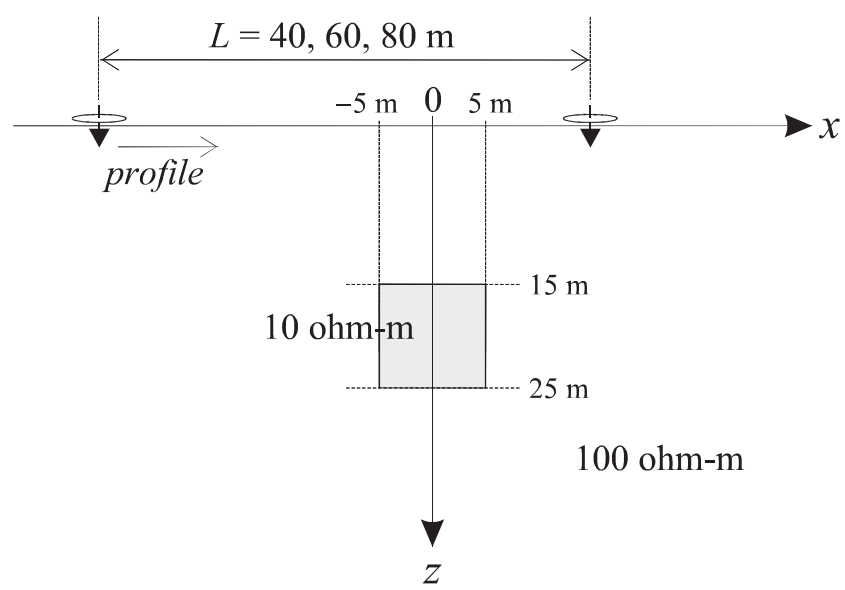

Fig. 1. A model with a conductive 2D block embedded in a homogeneous half-space, to test the accuracy of forward modelling and inversion algorithms. 
space of $100 \Omega . \mathrm{m}$. We calculated the HCP and VCP responses for three frequencies, $3 \mathrm{kHz}, 10 \mathrm{kHz}$, and $30 \mathrm{kHz}$. Source-receiver separations $(L)$ used were $40 \mathrm{~m}, 60 \mathrm{~m}$, and $80 \mathrm{~m}$.

Figures 2 and 3 show the modelling results, expressed as mutual impedances, for the HCP and VCP configurations, respectively, when $L=40 \mathrm{~m}$ for the three frequencies. These are calculated using our 2.5D scheme and using a finite element approach. In the finite element modelling we adapted the secondary field formulation described by Hohmann (1988). The cell size in our 2.5D modelling was $5 \mathrm{~m} \times 5 \mathrm{~m}$ while the finite element mesh size was $2.5 \mathrm{~m} \times 2.5 \mathrm{~m}$, both of which are small enough to enable convergence. In the HCP results (Figure 2), we can see a very good agreement between the results from both approaches except in the quadrature component at $30 \mathrm{kHz}$. This inconsistency seems to be due to a limitation of the LN
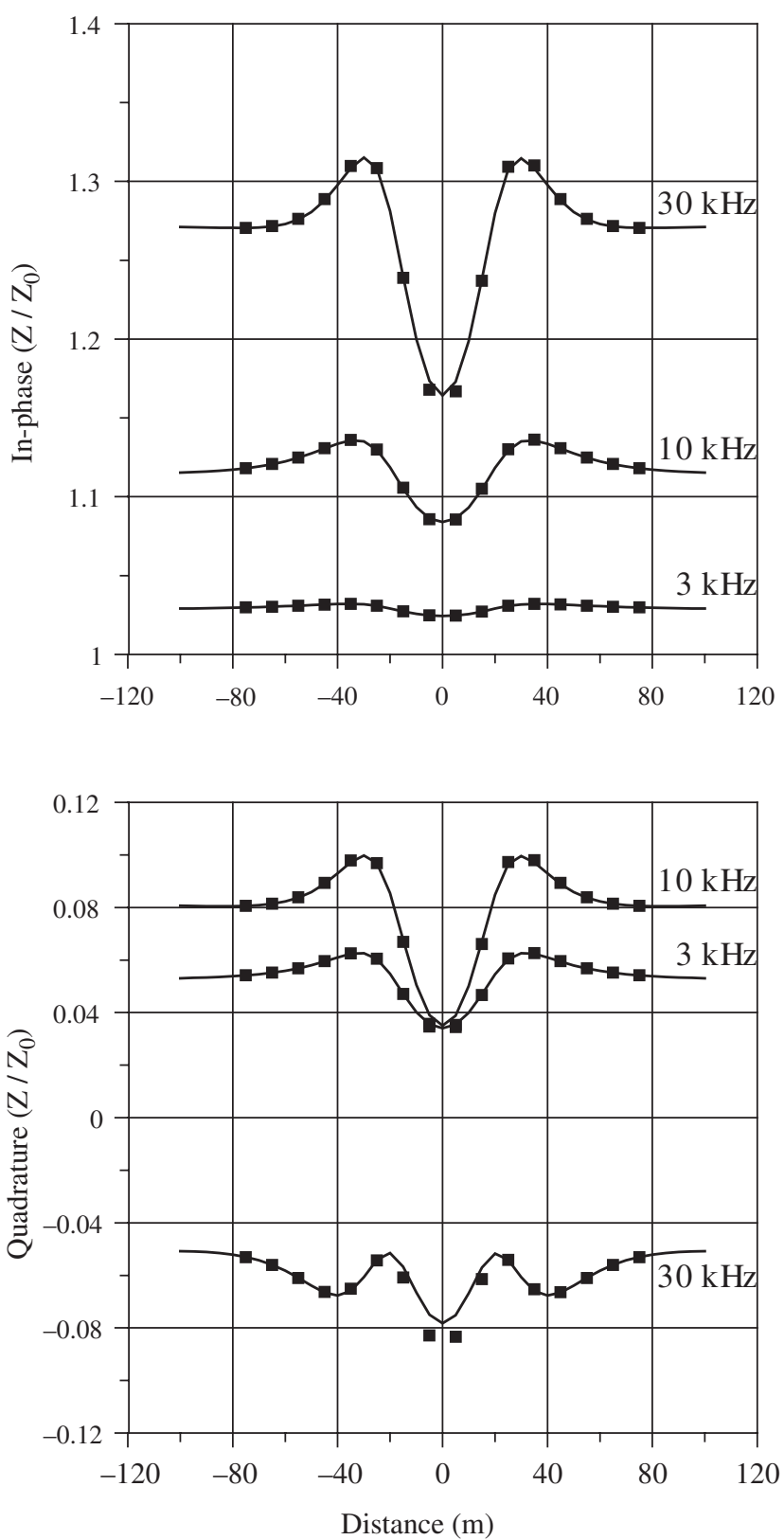

Fig. 2. In-phase (upper) and quadrature (lower) responses of the mutual impedance using HCP configuration with source-receiver separation of $40 \mathrm{~m}$ for the model shown in Figure 1. Solid lines are from our 2.5D LN approximation modelling while squares denote the results using $2.5 \mathrm{D}$ finite element approach approximation because the skin depth in the conductive block drops to some $9 \mathrm{~m}$ at this frequency. Although it is deliberately relaxed in the LN approximation, the basic assumption and limitation of the Born approximation, that inhomogeneities be 'electrically small', can hardly hold for this frequency. The results other than the quadrature component at $30 \mathrm{kHz}$ are quite satisfactory.

Figure 3 shows the in-phase and quadrature responses for the VCP configuration and again we can see a fairly good match of both results, so we conclude that the overall accuracy is acceptable when considering the conventional operating parameters used for loop-loop EM surveys. For this VCP configuration, we find that the horizontal variations of the responses are much smaller than for HCP configuration shown
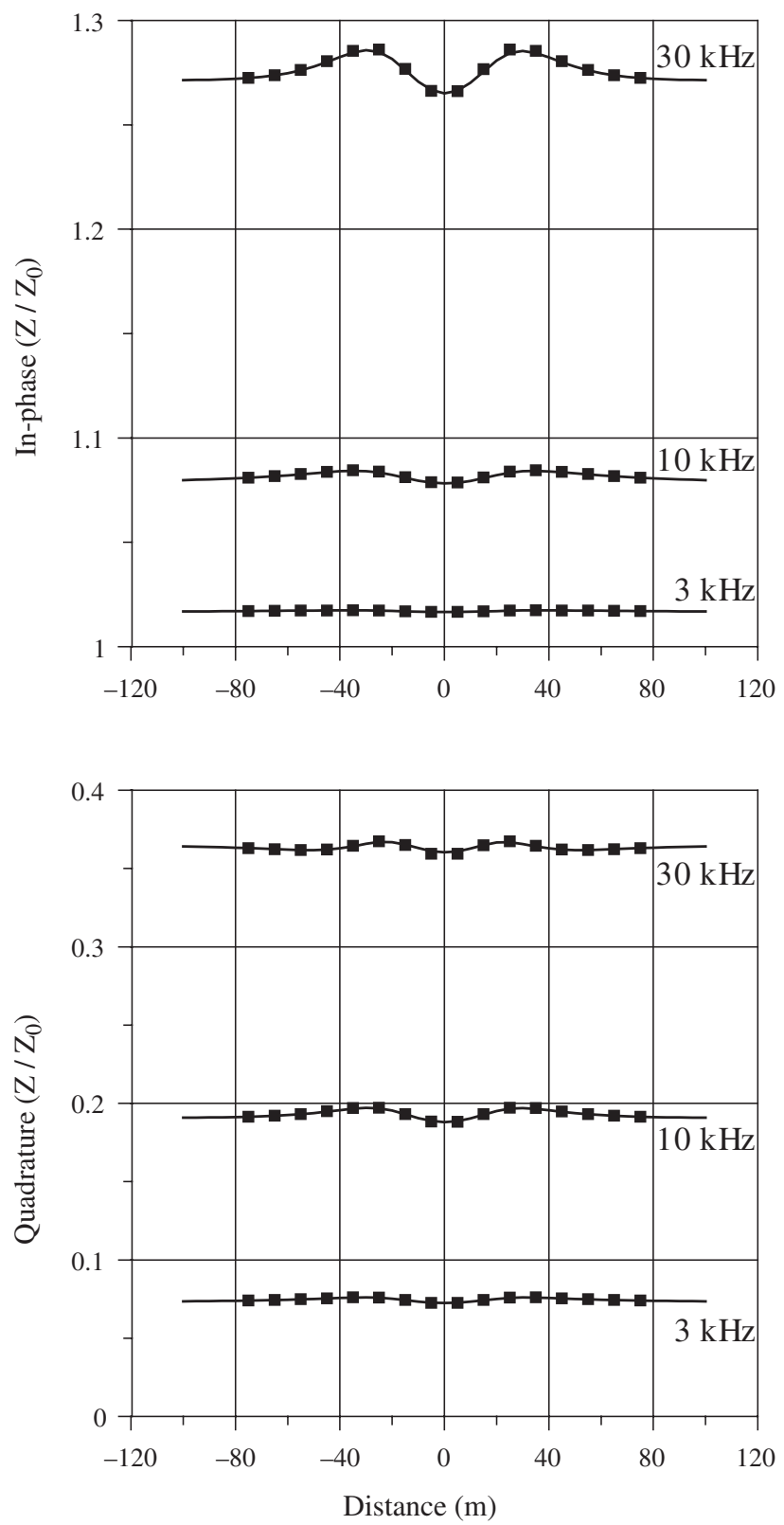

Fig. 3. In-phase (upper) and quadrature (lower) responses of the mutual impedance using VCP configuration with source-receiver separation of $40 \mathrm{~m}$ for the model shown in Figure 1. Solid lines are from our 2.5D LN approximation modelling while squares denote the results using $2.5 \mathrm{D}$ finite element approach. Note that the spatial variation of the response is much weaker than when using HCP configuration (Figure 2), which indicates the lower sensitivity of the configuration. 
in Figure 2. This low sensitivity is due to the weak coupling between source and receiver oriented in the strike direction; the magnetic dipole source in the direction of $y$ produces very weak incident electric fields along strike, if any, which implies low resolution in the inversion.

\section{Sensitivities}

Prior to the discussion of our inversion scheme, it is worth describing the sensitivity or Fréchet derivative, which is obtained without additional computing efforts in the inversion using our approximate integral equation approach. Taking the derivative of equation (12) with respect to the conductivity of the $j$-th cell,

$$
\begin{aligned}
\frac{\partial \tilde{\mathbf{H}}\left(x, k_{y}, z\right)}{\partial \sigma_{j}}= & \frac{\partial \tilde{\mathbf{H}}^{s}\left(x, k_{y}, z\right)}{\partial \sigma_{j}} \\
= & -\underline{\underline{\boldsymbol{\Omega}}}_{j}^{H} \cdot \tilde{\mathbf{E}}\left(x_{j}, k_{y}, z_{j}\right)-\sum_{k=1}^{N} \Delta \sigma_{k} \underline{\underline{\boldsymbol{\Omega}}}_{j}^{H} \\
& \cdot \frac{\partial \tilde{\mathbf{E}}\left(x_{k}, k_{y}, z_{k}\right)}{\partial \sigma_{j}},
\end{aligned}
$$

where

$$
\underline{\underline{\mathbf{\Omega}}}_{j}^{H}=\hat{z} \int_{S_{j}} \underline{\underline{\mathbf{G}}}^{H}\left(x-x^{\prime}, k_{y}, z ; z^{\prime}\right) d S^{\prime} .
$$

The sensitivity of electric field is also represented as

$$
\begin{aligned}
\frac{\partial \tilde{\mathbf{E}}\left(x_{k}, k_{y}, z_{k}\right)}{\partial \sigma_{j}} & =\frac{\partial \underline{\underline{\boldsymbol{\Gamma}}}_{k}}{\partial \sigma_{j}} \cdot \tilde{\mathbf{E}}^{p}\left(x_{k}, k_{y}, z_{k}\right) \\
& =-\underline{\tilde{\boldsymbol{\Gamma}}}_{k} \cdot \underline{\underline{\boldsymbol{\Omega}}}_{k, j} \cdot \underline{\underline{\boldsymbol{\Gamma}}}_{k} \cdot \tilde{\mathbf{E}}^{p}\left(x_{k}, k_{y}, z_{k}\right),
\end{aligned}
$$

where

$$
\underline{\underline{\boldsymbol{\Omega}}}_{k, j}=\hat{z} \int_{S_{j}} \underline{\underline{\mathbf{G}}}^{E}\left(x-x^{\prime}, k_{y}, z_{k} ; z^{\prime}\right) d S^{\prime} .
$$

Hence we arrive the following expression for the element of the sensitivity function as

$$
\begin{gathered}
A_{i j}=\frac{1}{2 \pi} \int_{-\infty}^{\infty}\left[-{\underline{\tilde{\boldsymbol{\Omega}}^{H}}}_{i, j}^{H} \cdot \tilde{\mathbf{E}}\left(x_{j}, k_{y}, z_{j}\right)+\sum_{k=1}^{N} \Delta \sigma_{k} \underline{\underline{\boldsymbol{\Omega}}}_{i, k}^{H} \cdot \underline{\tilde{\boldsymbol{\Gamma}}}_{k} \cdot \underline{\underline{\boldsymbol{\Omega}}}_{k, j}\right. \\
\left.\cdot \tilde{\mathbf{E}}\left(x_{k}, k_{y}, z_{k}\right)\right] e^{i k_{y} y} d k_{y},
\end{gathered}
$$

where

$$
\underline{\underline{\boldsymbol{\Omega}}}_{i, j}^{H}=\hat{z} \int_{S_{j}} \underline{\underline{\mathbf{G}}}^{H}\left(x_{i}-x^{\prime}, k_{y}, z_{i} ; z^{\prime}\right) d S^{\prime} .
$$

Note that the terms in the right hand side of equation (18) have already appeared in the computation of secondary magnetic fields using equations (12) and (13). In other words, we can get all the elements necessary for the calculation of Fréchet derivatives in the forward computation stage. We only need to solve the generalised inverse matrix to get the update of the model parameters without a heavy additional computing load, and thus we can reduce overall computing time to the order of iterative forward modelling.

\section{Inversion with a spatially variable Lagrangian multiplier}

The update vector for the model parameters at each iteration step of the least-squares inversion with second order smoothness constraint is determined by minimising the misfit, as

$$
\begin{aligned}
\delta \mathbf{m} & =\left[\mathbf{J}^{T} \mathbf{J}+\lambda\left(\partial^{2} \delta \mathbf{m}\right)^{T}\left(\partial^{2} \delta \mathbf{m}\right)\right]^{-1} \mathbf{J}^{T} \delta \mathbf{d} \\
& =\mathbf{J}^{-g} \delta \mathbf{d},
\end{aligned}
$$

where $\mathbf{J}$ is the Jacobian matrix with appropriate normalisation or weighting applied to the elements in equation (18), and $\mathbf{J}^{-g}$ is its generalised inverse, the normalised misfit vector is

$$
\delta \mathbf{d}=\frac{\mathbf{H}^{\text {obs }}-\mathbf{H}^{\text {calc }}}{\left|\mathbf{H}^{\text {obs }}\right|},
$$

$\left|\mathbf{H}^{\text {obs }}\right|$ are the absolute values of the observed data, and the modelparameter vector $\mathbf{m}$ has elements,

$$
m_{i}=\ln \left(\sigma_{i}\right)
$$

(Constable et al., 1987; Sasaki, 1989).

Note that we may incorporate an inequality constraint (Kim et al., 1999) if a priori information is provided through well logs etc., as

$$
\mathbf{m}^{\prime}=\ln \left(\frac{\mathbf{m}-\mathbf{m}_{\max }}{\mathbf{m}_{\min }-\mathbf{m}}\right),
$$

where $\mathbf{m}_{\max }$ and $\mathbf{m}_{\min }$ are the upper and lower bounds for the parameter vectors, respectively.

Determination of the Lagrangian multiplier, which balances the minimisation of data misfit and of the model roughness, may be a critical procedure to achieve both resolution and stability. Recently, Yi et al. (2003) introduced a simple and robust way of incorporating the Lagrangian multiplier as a spatial variable, dependent on sensitivity to the model parameters. They named this approach Active Constraint Balancing (ACB), in that the Lagrangian multiplier distribution is automatically calculated in each iteration step of the inversion. Yi et al. (2001) successfully applied it to the 3D imaging of the subsurface resistivity distribution using de resistivity survey data. We adapt their approach here to test its performance for the loop-loop EM data.

The parameter resolution matrix, which says how closely a particular estimate of the model parameter is to the true solution, can be defined as

$$
\mathbf{R}=\mathbf{J}^{-g} \mathbf{J}
$$

(Menke, 1984). Note that $\mathbf{R}=\mathbf{I}$ means a perfect resolution. Using the parameter resolution matrix we introduce BackusGilbert spread function, which is a measure of goodness of resolution,

$$
\operatorname{spread}(\mathbf{R})=\sum_{i=1}^{N} \sum_{j=1}^{N} w(i, j) R_{i, j}^{2},
$$

with its elements being

$$
S_{i}=\sum_{j=1}^{N} w(i, j) R_{i, j}^{2},
$$

where $w(i, j)$ is the geometrical distance between parameter block $i$ and $j$.

Equation (25) says that a larger spread of a particular model parameter indicates the lower resolution of that parameter or vice versa. Since perturbation of a parameter of low resolution has little effect on the resultant misfit, it is preferable to apply a strong constraint to that parameter in the inversion process. We can, therefore, define the spatially variable Lagrangian multiplier as a function of spread or resolution which, in turn, becomes a function of the location of the parameter block:

$$
\begin{aligned}
\log \left(\lambda_{i}\right)= & \log \left(\lambda_{\text {min }}\right)+\frac{\log \left(\lambda_{\text {max }}\right)-\log \left(\lambda_{\text {min }}\right)}{\log \left(S_{\max }\right)-\log \left(S_{\text {min }}\right)} \\
& \cdot\left\{\log \left(S_{i}\right)-\log \left(S_{\text {min }}\right)\right\},
\end{aligned}
$$


where the maximum and minimum values are the upper and the lower bounds of the Lagrangian multiplier and the spread, and are predefined after numerous tests (Yi et al., 2003).

Note the automatic determination of the Lagrangian multiplier set requires a small amount of additional time. However, because the evaluation of the parameter resolution matrix and spread function needs only simple matrix multiplication at each iteration step, it takes only a small fraction of forward computing time when the number of data is of the order of several hundred.

Figure 4 shows inversion results after five iterations with the conventional, fixed Lagrangian multiplier of unity, using $\mathrm{HCP}$ and VCP data calculated for the model shown in Figure 1. We used data at the three frequencies, $3 \mathrm{kHz}, 10 \mathrm{kHz}$, and $30 \mathrm{kHz}$, and for $L=40,60$ and $80 \mathrm{~m}$. The number of data used in each inversion was 342: 2 components $\times 3$ frequencies $\times$ number of data $(21+19+17$ for $L=40,60$ and $80 \mathrm{~m}$, respectively). We can see a blurred image of the conductive block due to the roughness term. The resistivity value for the VCP data is not close to the true one as predicted by the weak modelling responses in Figure 3.

Figure 5, on the other hand, shows the inversion results for the same data with the spatially variable Lagrangian multiplier set through the automated parameter resolution matrix and spread function analysis. We can see a more focused image for HCP data although there are still some artefacts along the blocks at a depth of $10 \mathrm{~m}$. Improvement of the resolution is remarkable for VCP data, where we can see conductive anomalies centred around the true one.

Figure 6 shows the distribution of the Lagrangian multiplier determined at the fifth iteration, and used for the reconstruction of images shown in Figure 5. We see the Lagrangian multipliers with small values, which in turn denote a highly resolvable area, are just above the conductor in the HCP configuration, while they are spread over the uppermost layer in the VCP configuration. Considering that the vertical magnetic dipole source in the HCP configuration generates TE mode incident EM fields along the profile line while the VCP generates TM mode, it is quite natural that the two configurations with different orientation show different sensitivity distributions. This example tells us that the inversion scheme with a spatially variable Lagrangian
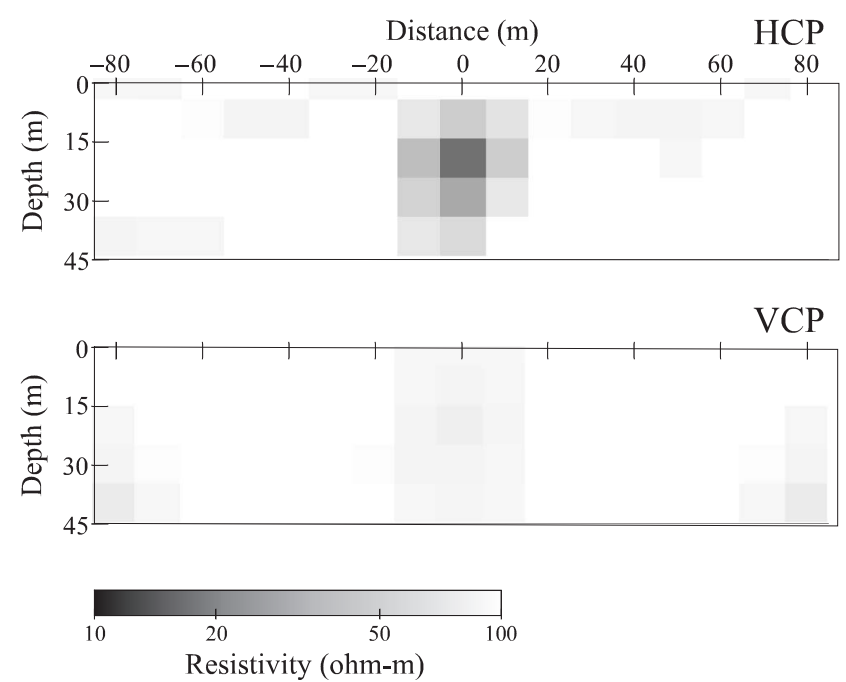

Fig. 4. Resulting images after the fifth iteration of inversion with a fixed Lagrangian multiplier of unity, using synthetic HCP (upper) and VCP (lower) data for the model shown in Figure 1. Total number of data at each inversion is 342 , including real and imaginary component, three frequencies, and three separations.
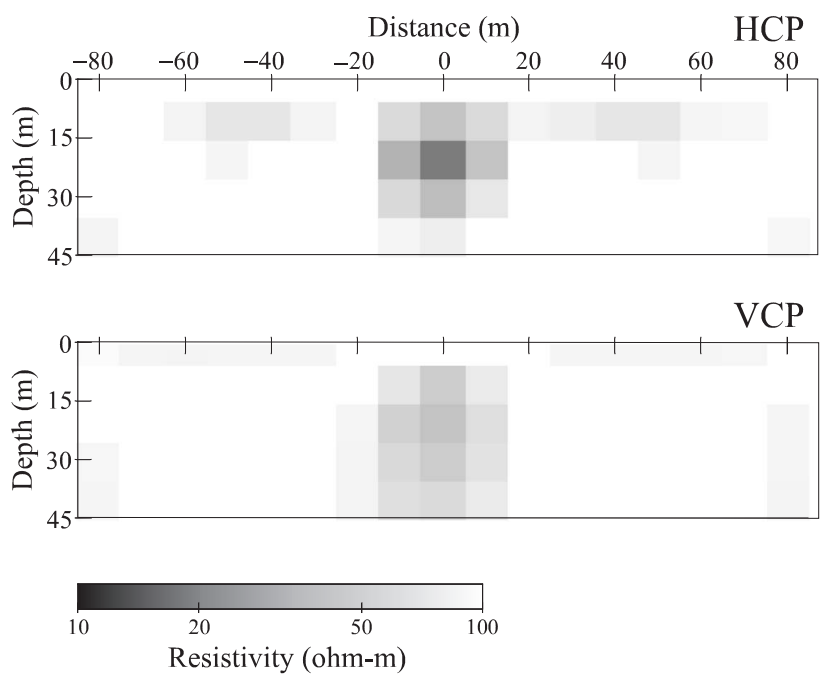

Fig. 5. Resulting images after the fifth iteration of inversion with spatially variable Lagrangian multipliers determined through parameter resolution matrix and spread function analysis. Synthetic HCP (upper) and VCP (lower) data for the model shown in Figure 1 was used in the inversion, as in Figure 4.
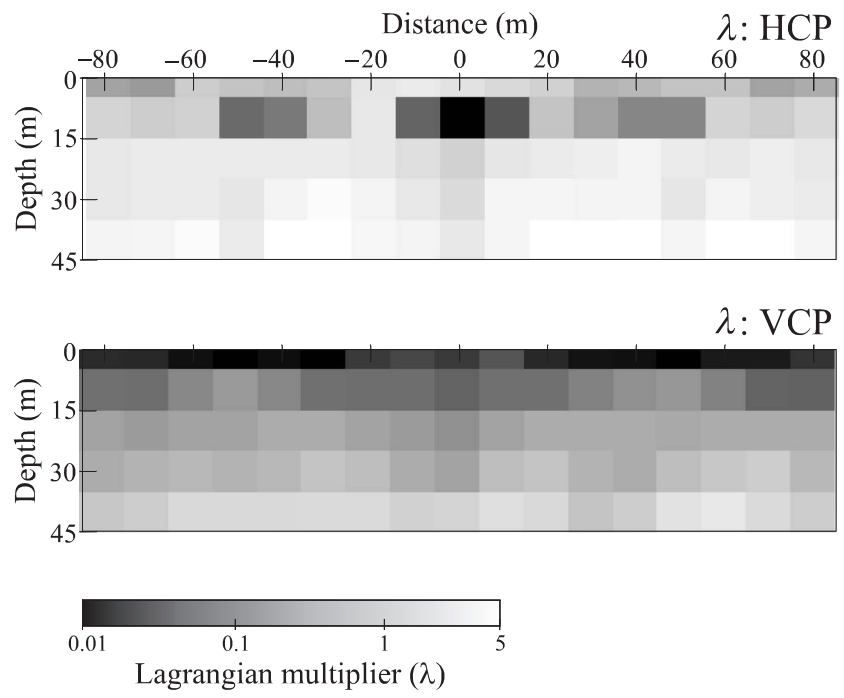

Fig. 6. Spatial distributions of Lagrangian multiplier for the images shown in Figure 5.

multiplier, based on sensitivity analysis, does provide an image of higher resolution.

\section{Incorporating the misfit variances}

As we can see from the modelling results in Figures 2 and 3, the data using HCP and VCP configuration show quite different sensitivities and the inversion results shown in Figures 4 and 5 confirmed this. We may simply expect that simultaneous inversion using both the HCP and VCP datasets would enhance the resolution, because it doubles the number of measured data. The upper two results shown in Figure 7 show, however, that this does not hold, at least for this example; the results are similar to Figures 4 and 5. Since the sensitivity of the data differs from configuration to configuration, the range of misfit also shows a different distribution. Consequently, minimising the misfit as used in equation (20) would lead to bias, affected by the dataset having larger misfit variance. Note that we can also see different sensitivities between in-phase and quadrature components, or between frequencies, even for the same sourcereceiver configuration (see Figures 2 and 3), but they mostly 
HCP \& VCP, constant $\lambda$ Distance $(\mathrm{m})$

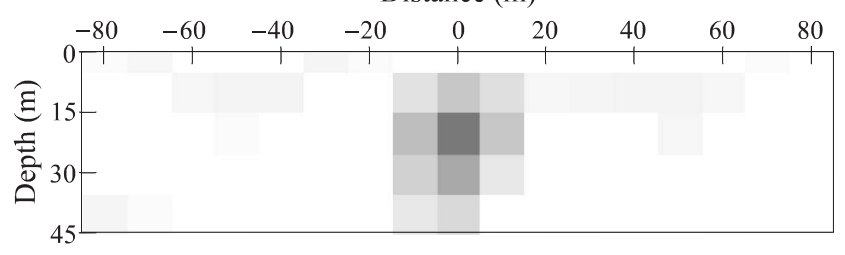

HCP \& VCP, variable $\lambda$

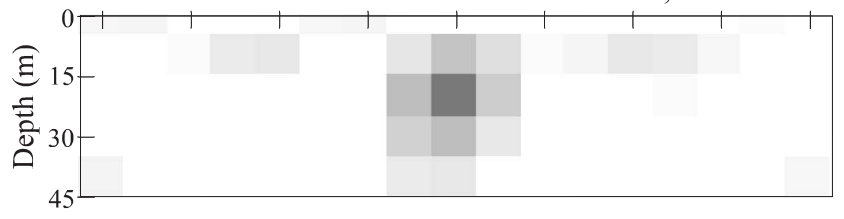

HCP \& VCP, variable $\lambda$, weighting
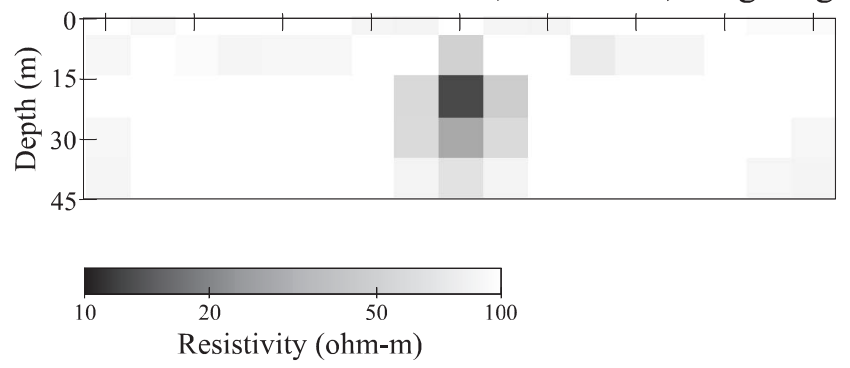

Fig. 7. Resulting images with various inversion parameters after fifth iteration of inversion using the HCP and VCP data simultaneously. The same data as in Figure 5 was used in the inversion so the number of data in the inversion doubles to 684 .

include the information on the subsurface resistivity distribution themselves.

The data resolution matrix, which says how closely a particular estimate of the data is to the measured value, and the data spread function, can also be defined similarly to those for model parameters as in equations (24) through (26) (Menke, 1984). In data resolution matrix analysis, we confirmed very large differences of normalised misfits, expressed in equation (21), between different configurations. We, therefore, incorporate a weighting scheme according to the standard deviations or variances of the misfits of each dataset and redefine the equation for the parameter update as

$$
\delta \mathbf{m}=\left[\mathbf{J}^{T} \mathbf{W}_{d}^{-1} \mathbf{J}+\lambda\left(\partial^{2} \delta \mathbf{m}\right)^{T}\left(\partial^{2} \delta \mathbf{m}\right)\right] \mathbf{J}^{T} \mathbf{W}_{d}^{-1} \delta \mathbf{d},
$$

where

$$
\begin{gathered}
\lambda=\operatorname{diag}\left(\lambda_{i}\right), \quad i=1, \ldots, N, \\
\mathbf{W}_{d}=\frac{1}{\breve{\sigma}^{2}} \operatorname{diag}\left(\breve{\sigma}_{i c}^{2}\right), \quad i c=1,2,
\end{gathered}
$$

and the misfit variance is

$$
\breve{\sigma}^{2}=\frac{1}{M-1} \sum_{j=1}^{M}\left(\delta d_{j}-\delta \bar{d}\right),
$$

where $M$ is the number of measured data, $\delta \bar{d}$ the mean of data misfit, and $\breve{\sigma}_{i c}^{2}$ is the misfit variance of $i c$-th configuration data. Note that this normalisation by misfit variance balances the overall misfit so that the inversion accounts all the necessary information included in the data. The bottom image of Figure 7 shows the results incorporating this weighting along with the spatially variable Lagrangian multiplier scheme. We see the bottom image is focused better than the upper or the middle ones, and the recovered value is close to the true one.

Figure 8 illustrates the effect of the normalisation or weighting. We show only quadrature component data for the sake of simplification, and thus the number of data used in the inversion shown in Figure 7 reduces to 342. The upper plot shows the data misfit $(\delta \mathbf{d})$ at the initial iteration step; the first half is for the HCP configuration while the rest is for VCP data. Since we start with a homogeneous background model, we can see the trend is similar to the model responses, and thus the misfits are much smaller for the VCP than for the HCP configuration. When we apply weighting to the Jacobian based on the misfit variance as in equation (30), the misfit becomes more balanced as shown in the lower plot. Note that we do not normalise the statistics according to frequency, because the decay and the variation of the responses to frequency themselves have important information about the subsurface resistivity distribution.

Figure 9 shows another example, using a double block model, one of which is conductive, $10 \Omega . \mathrm{m}$, and the other is resistive, $1000 \Omega . m$, embedded in a homogeneous half-space of $100 \Omega . m$ (top image). In this example, we use the spatially variable Lagrangian multiplier scheme for all results. As we can see in
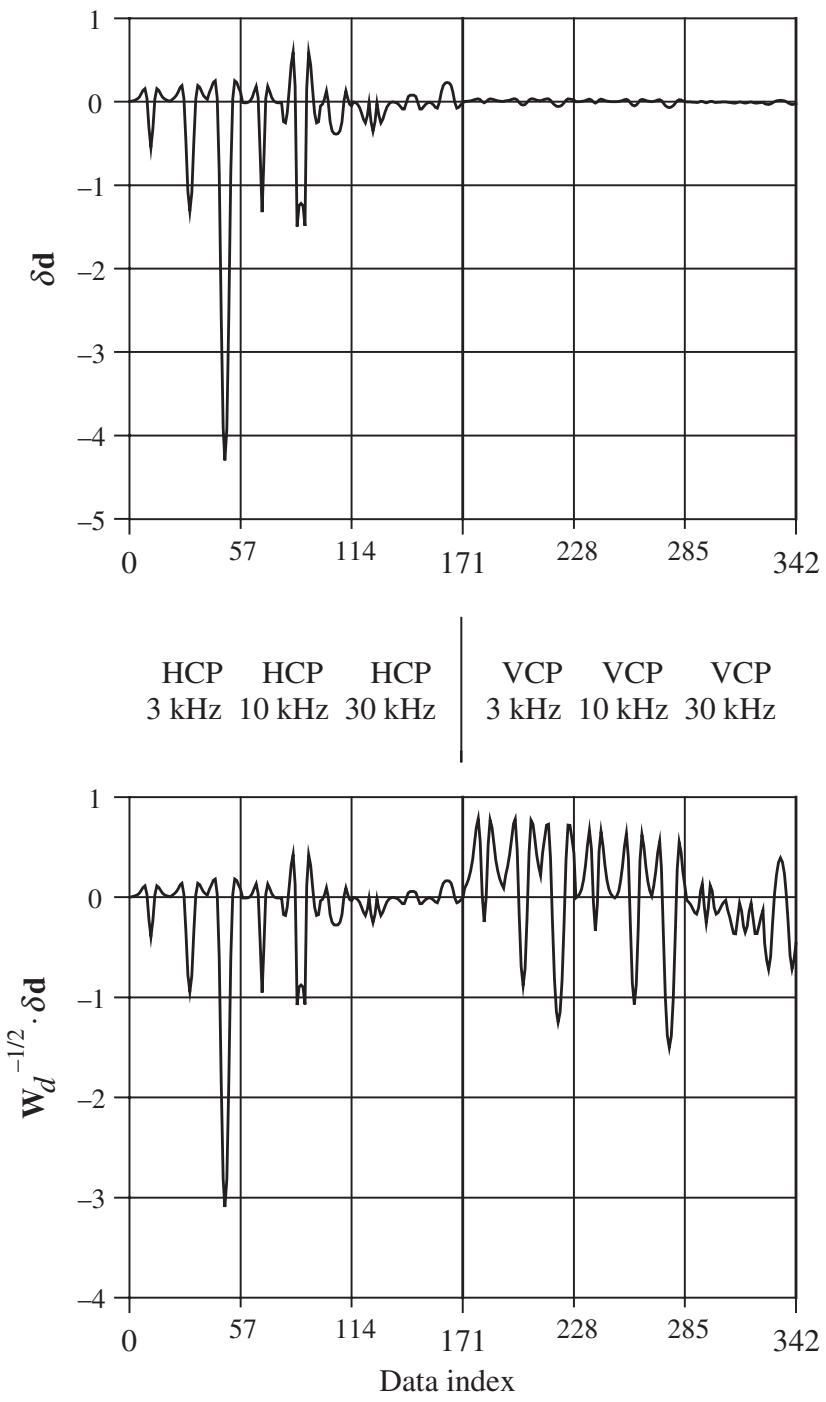

Fig. 8. Data misfit (upper) and weighted data misfit (lower) using misfit variances of quadrature components at the first iteration of the simultaneous inversion shown in Figure 7. 

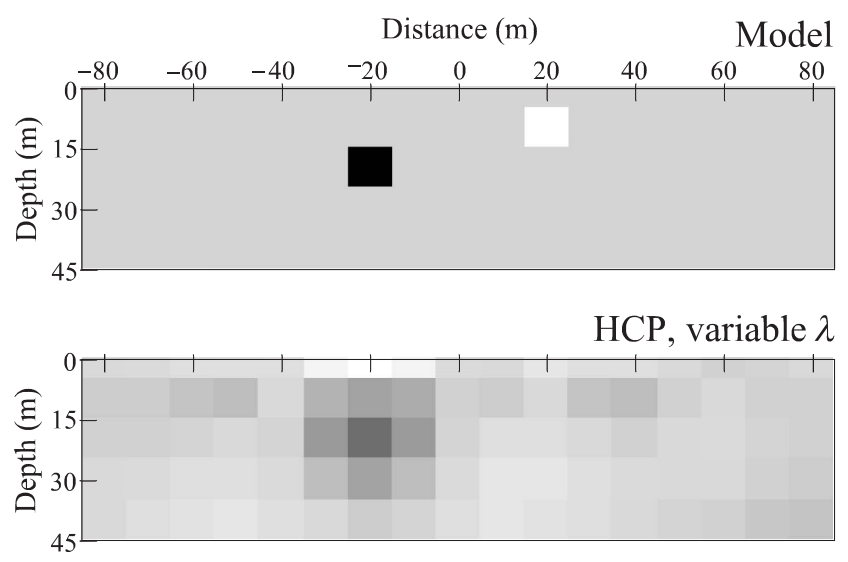

$\mathrm{VCP}$, variable $\lambda$

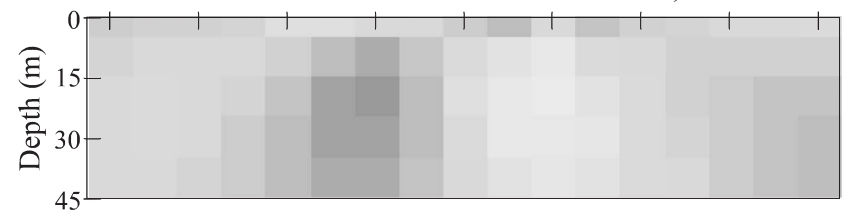

HCP \& VCP, variable $\lambda$

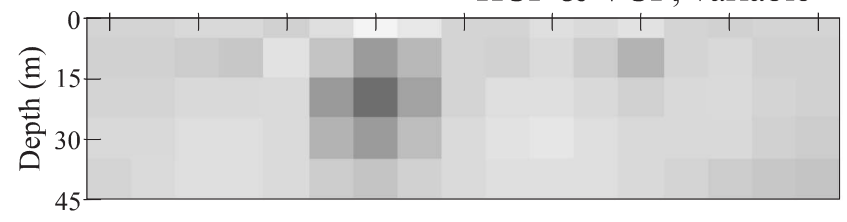

HCP \& VCP, variable $\lambda$, weighting
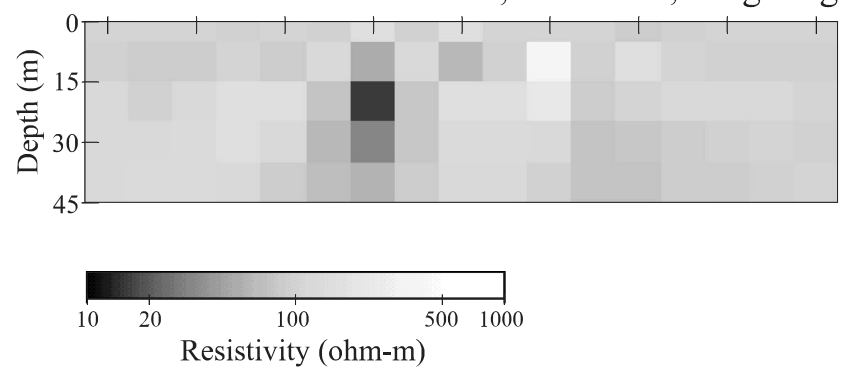

Fig. 9. Inversion results for a model including conductive $(10 \Omega . \mathrm{m})$ and resistive $(1000 \Omega . \mathrm{m})$ blocks in a homogeneous half-space of $100 \Omega . \mathrm{m}$. We can identify the resistive block only when using the misfit-based weighting scheme with the Jacobian matrix.

Figure 9, only the lowermost image, using the weighting scheme, shows the existence of the high-resistivity block. Since the VCP data is more sensitive to the properties of the shallow subsurface, the third image does show a relatively high resistivity zone, but it is blurred and the resistivity values are not close to the true one. Even in the lowermost result, of course, the image is somewhat blurred due to the effect of the smoothness constraint, and the value of the high-resistivity block is just half of the true value. Considering, however, that the conductivity contrast term in equation (1) becomes a small negative value for a resistive block, this result is sufficiently acceptable.

\section{Application to field data}

We applied the developed algorithm to field data to test its practical performance. We used Geonics EM34-3XL loop-loop EM system which operates with three coil separations and frequencies; $10 \mathrm{~m}$ and $6400 \mathrm{~Hz}, 20 \mathrm{~m}$ and $1600 \mathrm{~Hz}$, and $40 \mathrm{~m}$ and $400 \mathrm{~Hz}$, all of which correspond to a single induction number. The test site was located in an agricultural field in Korea,
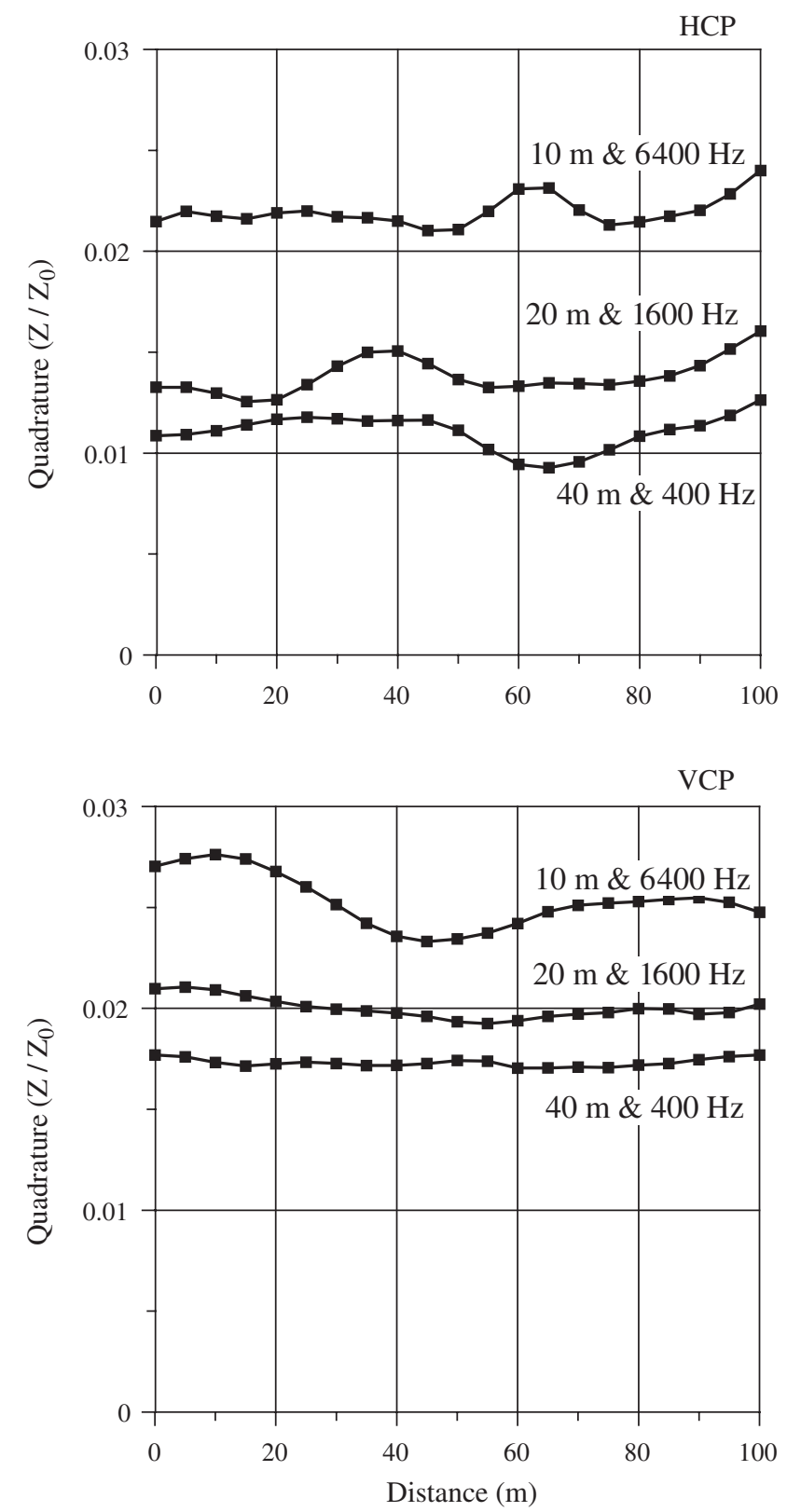

Fig. 10. Field data for HCP (upper) and VCP (lower) configuration, using a Geonics EM34-3XL loop-loop EM system. The quadrature components of mutual inductance, converted from the measured apparent conductivities using near-field formula, are shown. Squares denote the midpoint of source and receiver; measurements were taken every $5 \mathrm{~m}$.

covered with alluvial deposits some 10 to $20 \mathrm{~m}$ in thickness. Figure 10 shows the measured data at every $5 \mathrm{~m}$ along a profile of $100 \mathrm{~m}$. Since the EM34-3XL system measures the quadrature components only and reads the responses in terms of the apparent conductivity, we converted them to the quadrature components of the mutual inductance using the near-field formula (Spies and Frischknecht, 1991). The responses significantly deviate from those of a layered earth, and again those for VCP configuration show smaller variation than HCP.

Figure 11 shows the resultant images derived from inversion of the different datasets. We can see 2D structure in the image using the HCP data while the result using VCP data merely shows layer features. The image resulted from the simultaneous inversion using both HCP and VCP data, on the other hand, shows more details, which delineate the alluvial deposits. Note that we used the spatially variable Lagrangian scheme in all 

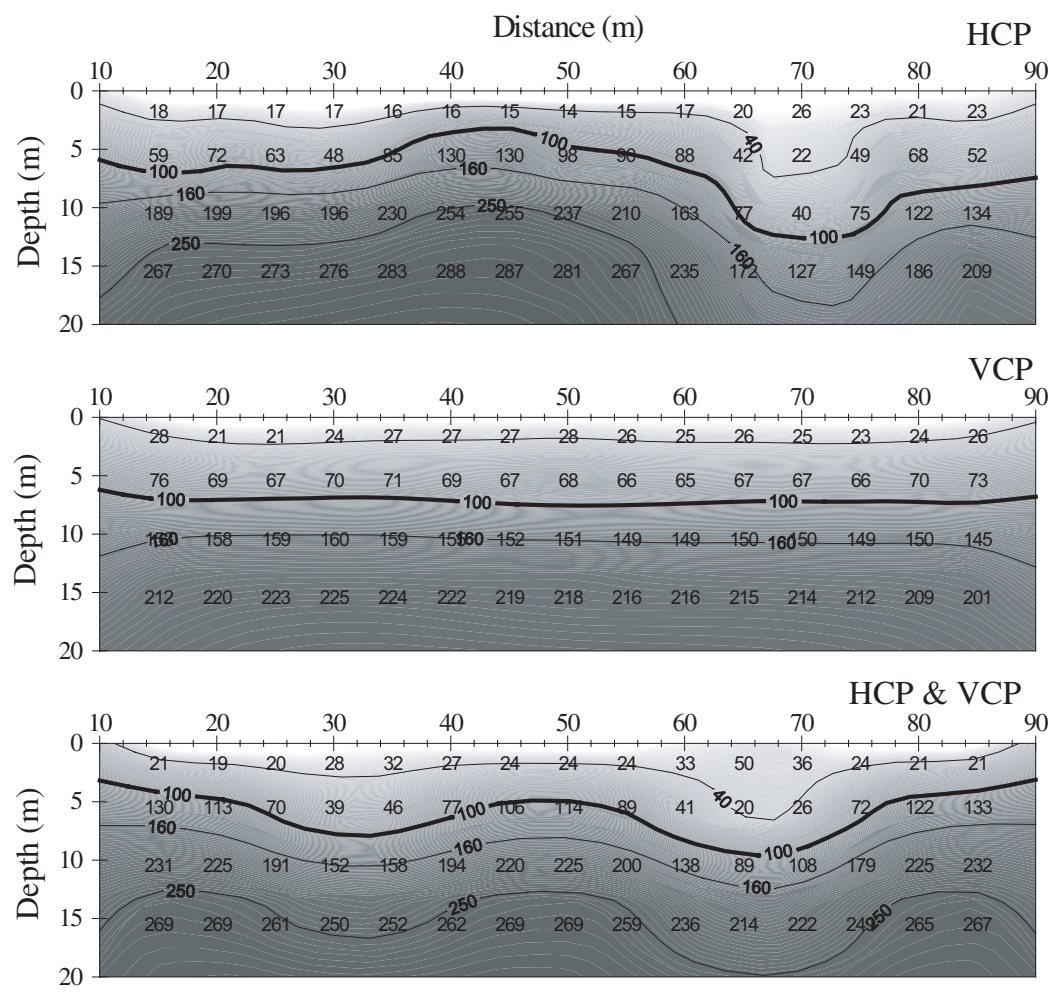

Fig. 11. Inversion results of the three sets of field data shown in Figure 10.

\section{Field data pseudosection}

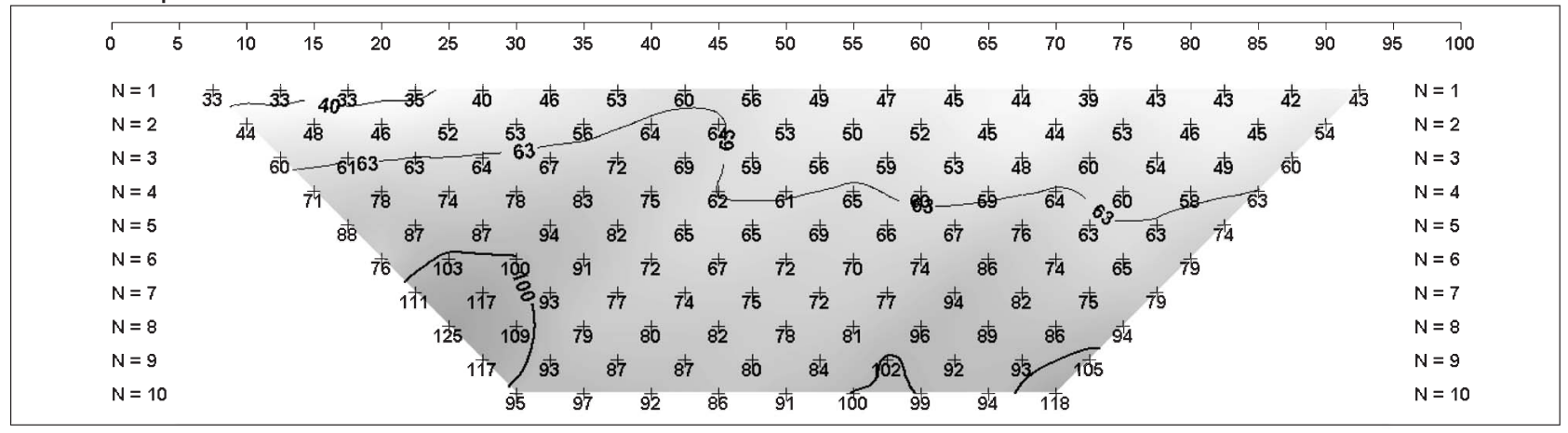

\section{2-D Resistivity structure}

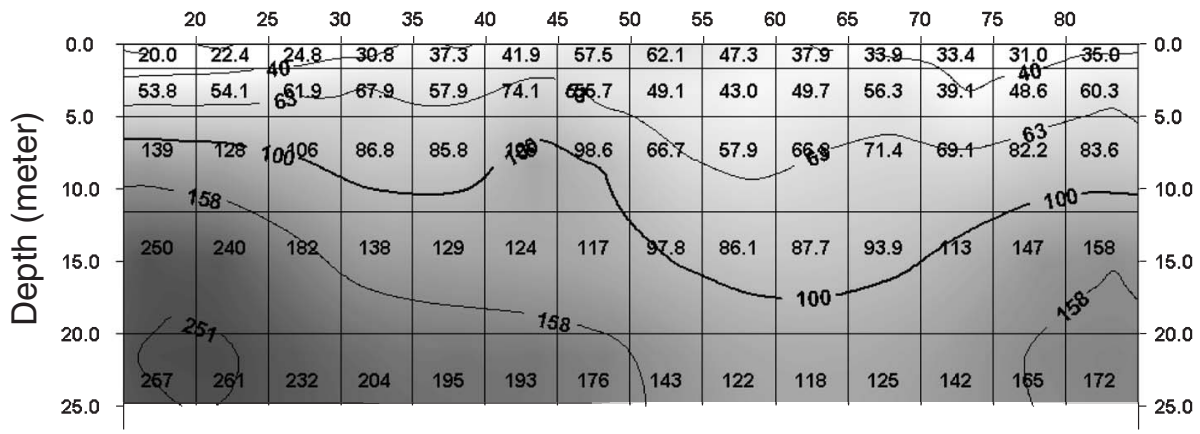

Fig. 12. Apparent resistivity pseudosection (upper) from dipole-dipole resistivity survey data along the same profile as the EM survey in Figures 10 and 11 , and the 2D resistivity image resulting from 2.5D finite difference inversion (lower). The dipole length used was also $5 \mathrm{~m}$.

inversion processes, and applied the weighting scheme in the simultaneous inversion of both HCP and VCP data.

To verify the performance of our inversion algorithm, we have conducted a resistivity survey with a $5 \mathrm{~m}$ dipole-dipole array, along the same profile. Figure 12 shows the apparent resistivity pseudosection of the field data, and the resistivity distribution image resulted from 2.5D finite difference inversion. Comparing the images in Figures 11 and 12, the resistivity values of the EM image are slightly high, especially in deeper parts, which makes the depth of the alluvium appear to be less than 
the dc survey result. The overall trend, however, matches fairly well. Considering that we used only three separations in the EM survey, and that they even correspond to a single induction number, this fine match between the results is quite convincing evidence that our inversion algorithm also works properly for field data.

\section{Discussion and conclusions}

We have described an LN approximation to the 2.5D EM integral equation solution, and least-squares inversion with a spatially variable Lagrangian multiplier set and weighting of the Jacobian using variances of data misfits. Comparing responses calculated for a conductive block model over some frequency and sourcereceiver separation ranges with the results of finite element modelling, we conclude that our modelling scheme provides accurate results enough to be used for inversion.

Through an analytic formulation of the sensitivities, adopting the approximation, we can reduce the computing time for the inversion to the order of the iterative forward modelling time, even when incorporating the various analyses for enhancing the resolution. Incorporating the automated determination of the spatially variable Lagrangian multiplier as a function of the sensitivity to model parameters through the parameter resolution matrix and spread function analysis, we could enhance the resolution of the images. Resulting distributions of the Lagrangian multiplier are quite different from the constant, homogeneous one, which shows that our scheme properly reflects the sensitivity to model parameters.

The large difference in sensitivity between the HCP and VCP configurations prevents the resolution of the image from being enhanced when using both datasets simultaneously in inversion. Taking into account that the variances of the misfits are different from configuration to configuration, we implemented a weighting scheme of Jacobian based on the misfit variances. Testing the performance of the weighting, along with the spatially variable Lagrangian multiplier scheme, with a double block model including a resistive body as well as conductive one, we found a remarkable enhancement of resolution.

We, then, applied our method to field data and compared the results with a dipole-dipole resistivity survey image. We found that the newly developed algorithm provided an image comparable to that of the dc resistivity survey although the number of separations or frequencies in the EM survey did not seem enough to cover the same depth range as the dc resistivity survey.

The newly developed algorithm is stable; all the inversion results shown here converged in the fifth iteration, and it runs fast; taking less than an hour to invert data from 21 stations, 3 separations, 3 frequencies, and two configurations on a PC platform equipped with Pentium III $900 \mathrm{MHz}$ CPU. We expect that the algorithm developed in this study would be a useful tool in imaging the subsurface where good contact with the ground is not possible, or where the ground surface is contaminated, such as in environmental applications.

\section{Acknowledgments}

This work was supported by Basic Research Project of Korea Institute of Geoscience and Mineral Resources (KIGAM) funded by the Ministry of Science and Technology of Korea. We also thank Dr. Jeong Sul Son of KIGAM for providing the finite element modelling results.

\section{References}

Chave, A. D., 1983, Numerical integration of related Hankel transforms by quadrature and continued fraction algorithm: Geophysics $\mathbf{4 8}$, 1671-1686. doi: 10.1190/1.1441448

Constable, S., Parker, L. P., and Constable, C. G., 1987, Occam's inversion: a practical algorithm for generating smooth models from electromagnetic sounding data: Geophysics 52, 289-300. doi: 10.1190/1.1442303

Frischknecht, F. C., Labson, V. F., Spies, B. R., and Anderson, W. L., 1991, Profiling methods using small sources, in M. N. Nabighian ed., Electromagnetic methods in applied geophysics - Applications, 105-270: Society of Exploration Geophysicists.

Habashy, T. M., Groom, R. W., and Spies, B. R., 1993, Beyond the Born and Rytov approximation: a nonlinear approach to electromagnetic scattering: Journal of Geophysical Research 98, 1759-1775.

Hohmann, G. W., 1975, Three-dimensional induced polarization and electromagnetic modelling: Geophysics 40, 309-324. doi: 10.1190/ 1.1440527

Hohmann, G. W., 1988, Numerical modeling for electromagnetic methods of geophysics, in M. N. Nabighian, ed., Electromagnetic methods in applied geophysics - Theory, 313-363: Society of Exploration Geophysicists.

Kim, H. J., Song, Y., and Lee, K. H., 1999, Inequality constraint in leastsquares inversion of geophysical data: Earth Planets Space 51, 255-259.

Menke, W., 1984, Geophysical data analysis: discrete inverse theory: Academic Press, Inc.

Sasaki, Y., 1989, Two-dimensional joint inversion of magnetotelluric and dipole-dipole resistivity data: Geophysics 54, 254-262. doi: 10.1190/1.1442649

Spies, B. R., and Frischknecht, F. C., 1991, Electromagnetic sounding, in M. N. Nabighian, ed., Electromagnetic methods in applied geophysicsApplications, 285-425: Society of Exploration Geophysicists.

Torres-Verdin, C., and Habashy, T. M., 1994, Rapid 2.5-D forward modeling and inversion via a new non-linear scattering approximation: Radio Science 29, 1051-1079. doi: 10.1029/94RS00974

Won, I. J., Keiswetter, D. A., Fields, G. R. A., and Sutton, L. C., 1996, GEM-2: a new multifrequency electromagnetic sensor: Journal of Environmental \& Engineering Geophysics 1, 129-137.

Yi, M.-J., Kim, J.-H., Song, Y., Cho, S.-J., Chung, S.-H., and Suh, J.-H., 2001, Three-dimensional imaging of subsurface structures using resistivity data: Geophysical Prospecting 49, 483-497. doi: 10.1046/j.1365-2478. 2001.00269.x

Yi, M.-J., Kim, J.-H., and Chung, S.-H., 2003, Enhancing the resolving power of the least-squares inversion with active constraint balancing: Geophysics 68, 931-941. doi: 10.1190/1.1581045

Manuscript received 27 August 2007; revised manuscript accepted 8 October 2007 


\section{루프-루프 전자탐사자료의 효과적인 2.5 차원 역산}

송윤호 ${ }^{1}$, 김정호 $^{2}$

요 약: 2.5차원 전자탐사 적분방정식의 확장된 Born 근사해 또는 국소 비선형 근사에 기초하여 루프-루프 전자탐사 역산 알고리듬이 개발되었다. 송수신 배열은 수평 동일면( $\mathrm{HCP})$ 또는 수직 동일면(VCP) 방식이고, 다중 주파수 및 다중 송수신 간격을 포함할 수 있으며 $\mathrm{PC}$ 에서 작동된다.

안정적이고 고해상도를 유지하는 역산이 가능하도록 변수분해 행렬과 Backus-Gilbert 분산 함수 분석을 통해 감도 분포의 함수로서의 공간적으로 변화하는 최적 Lagrange 곱수 결정 알고리듬을 포함하였다. $\mathrm{HCP}$ 와 VCP 배열 자료가 지하 전기비저항 구조에 따라 서로 다른 감도를 가짐에 따라 동시 역산에서 안정성과 해상도에 영향을 미치게 되므로, 계산값과 측정값 차의 분산에 따라 가중치를 적용하는 방식을 도입하였다.

모델링 코드의 정확성은 통상적으로 루프-루프 전자탐사에서 사용하는 주파수 및 송수신 간격 범위에서 유한차분법에 의해 계산된 결과와의 비교를 통하여 증명되었다. 개발된 역산 알고리듬은 먼저 반무한 공간내 전도체 및 저항체가 포함된 모델에 대한 계산자료에 적용되어 성능이 입증되었다. 현장자료에 적용하고 그 결과 영상을 전기비저항 탐사자료에 대한 역산 결과와 비교하여, 의미있는 지하구조의 영상을 얻을 수 있음을 확인하였다.

주요어 : 전자탐사, 2.5 차원 역산, 국소 비선형 근사

\section{ループ・ループ電磁探査法データの効率的な 2.5 次元インバージョン 宋 允鎬 (ソン ユンホ) ${ }^{1} \cdot$ 金 楨浩 (キム ジョンホ) ${ }^{2}$}

要 旨: 電磁場散乱問題を取扱う 2.5 次元積分方程式の近似解である局在化非線形近似あるいは拡張ボルン近似に基づいて, 我々はループ・ループ電磁探査データのインバージョンアルゴリズムを開発した。送信ループと受信ループの配置は，水平同 一平面(HCP) あるは鉛直同一平面(VCP) 配置を取扱うことができる。そしてマルチ周波数とマルチオフセット（送受信間距 離）のデータを併せて用いることが可能である。インバージョンコードは計算負荷をかけずにパーソナルコンピュータ上で駆 動する。

インバージョンにおける安定な高分解能性能を実現するために, パラメータ解像度行列とバッカスーギルバートスプレッド 関数解析に基づき, 感度分布に応じて空間的に変化するラグランジュ乗数を最適化するアルゴリズムを実装した。 HCP と VCP 配置のデータを同時にインバージョンする際に, 異なる送受信ループ配置の特性が, 比抵抗構造に対して調和しない感度分布 を有し, インバージョン結果の安定性や分解能に影響を与えることを考慮して, 測定データと計算值の当てはめ誤差の分散に 基づいて重み付けを行う手法を採用した。

開発したモデリングコードの精度は, ループ・ループ電磁探査システムで通常使用されている周波数, 導電率そして送受信 ループ配置の範囲について, 2.5 次元有限要素法によるモデリング結果との比較により検証した。最初, インバージョンの性 能を確認するために, 半無限均質大地中に低比抵抗と高比抵抗の不均質異常体が存在するモデルに対する数值データにインバ ージョンを適用した。そして実データにインバージョンを適用し，比抵抗法データのインバージョン結果との比較で，新規に 開発したアルゴリズムにより，合理的な地下のイメージが得られることがわかった。

\section{キーワード : 電磁探査, 2.5 次元, インバージョン, 局在化非線形近似}

1 한국지질자원연구원 지하수지열연구부

305-350 대전시 유성구 가정동 30

2 한국지질자원연구원 지반탐사연구실

\author{
1 韓国地質資源研究院 地下水地熱研究部 \\ 2 韓国地質資源研究院 地盤探査研究室
}

